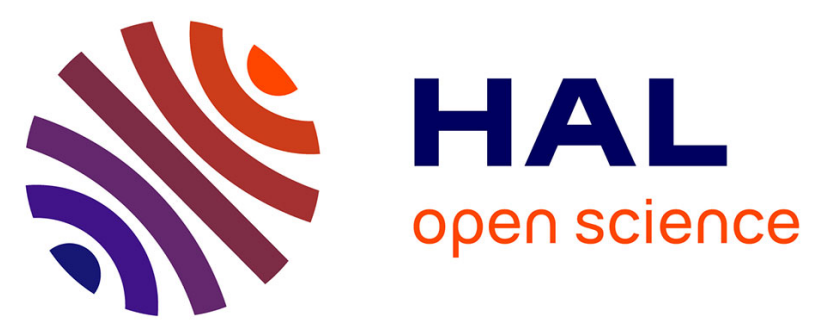

\title{
A contribution to the knowledge of scutacarid mites (Acari: Pygmephoroidea: Scutacaridae) associated with Coleoptera and Hymenoptera (Arthropoda: Insecta) from northwestern Iran
}

\author{
Mohammad Sobhi, Hamidreza Hajiqanbar, Azim Mortazavi
}

\section{To cite this version:}

Mohammad Sobhi, Hamidreza Hajiqanbar, Azim Mortazavi. A contribution to the knowledge of scutacarid mites (Acari: Pygmephoroidea: Scutacaridae) associated with Coleoptera and Hymenoptera (Arthropoda: Insecta) from northwestern Iran. Acarologia, 2017, 57 (4), pp.1103-1111. 10.24349/acarologia/20174222 . hal-01598605

\section{HAL Id: hal-01598605 \\ https://hal.science/hal-01598605}

Submitted on 29 Sep 2017

HAL is a multi-disciplinary open access archive for the deposit and dissemination of scientific research documents, whether they are published or not. The documents may come from teaching and research institutions in France or abroad, or from public or private research centers.
L'archive ouverte pluridisciplinaire HAL, est destinée au dépôt et à la diffusion de documents scientifiques de niveau recherche, publiés ou non, émanant des établissements d'enseignement et de recherche français ou étrangers, des laboratoires publics ou privés. 


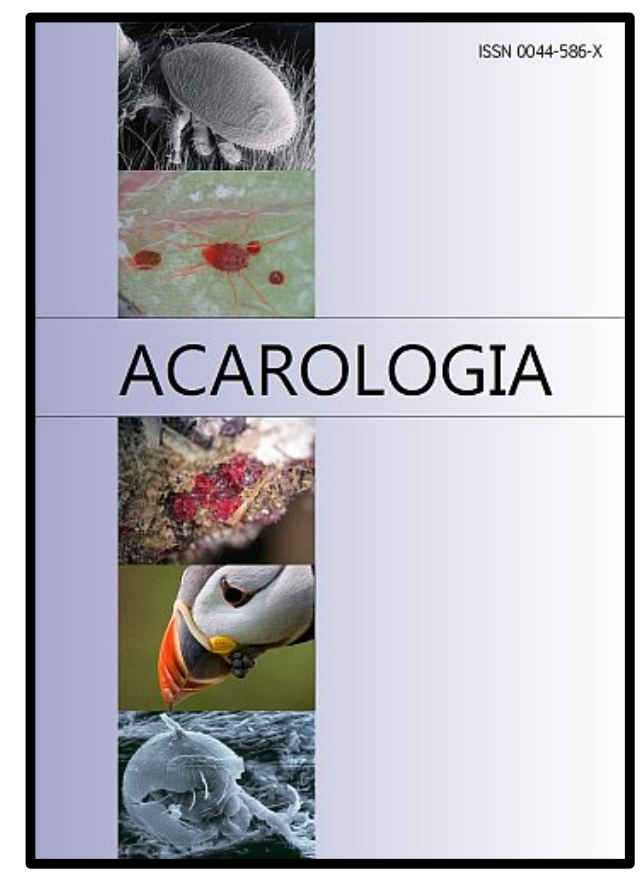

\section{ACAROLOGIA}

A quarterly journal of acarology, since 1959

Publishing on all aspects of the Acari

All information:

http://www1.montpellier.inra.fr/CBGP/acarologia/ acarologia@supagro.inra.fr

\section{OPEN ACCESS}

\section{Acarologia is proudly non-profit, with no page charges and free open access}

Please help us maintain this system by encouraging your institutes to subscribe to the print version of the journal and by sending us your high quality research on the Acari.

Subscriptions: Year 2017 (Volume 57): $380 €$ http://www1.montpellier.inra.fr/CBGP/acarologia/subscribe.php

Previous volumes (2010-2015): $250 € /$ year (4 issues)

Acarologia, CBGP, CS 30016, 34988 MONTFERRIER-sur-LEZ Cedex, France

The digitalization of Acarologia papers prior to 2000 was supported by Agropolis Fondation under the reference ID 1500-024 through the « Investissements d'avenir » programme

(Labex Agro: ANR-10-LABX-0001-01)
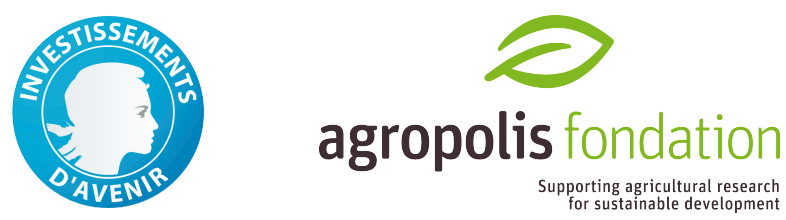

Acarologia is under free license and distributed under the terms of the

Creative Commons-BY-NC-ND which permits unrestricted non-commercial use, distribution, and reproduction in any medium, provided the original author and source are credited. 


\title{
A contribution to the knowledge of scutacarid mites (Acari: Pygmephoroidea: Scutacaridae) associated with Coleoptera and Hymenoptera (Arthropoda: Insecta) from northwestern Iran
}

\author{
Mohammad SOBHI, Hamidreza HAJIQANBAR ${ }^{\bowtie}$ and Azim MoRTAZAVI
}

(Received 07 June 2017; accepted 18 July 2017; published online 29 September 2017; edited by Marie-Stéphane TIXIER)

Department of Entomology, Faculty of Agriculture, Tarbiat Modares University, 14115-336, Tehran, Iran. Sobhimohammad7@yahoo.com; (凶) hajiqanbar@modares.ac.ir;azim.mortazavi@yahoo.com

\begin{abstract}
During the survey of heterostigmatic mites (Acari: Prostigmata) associated with insects in northwestern Iran, Ardabil province, 11 species from three genera of the family Scutacaridae were identified: Heterodispus (one species), Scutacarus (three species) and Imparipes (seven species). Among these, three species are recorded for the first time in Asia including Iran: Imparipes (Imparipes) rafalskii Dastych, 1978, I. (I.) comatus Mahunka, 1970 and Scutacarus remissus Khaustov, 2008. I. (I.) lentus Khaustov, 2008 is recorded for the first time in Iran. All host insects were captured directly from their habitats. Eight new insect host records are reported and the world distribution of these mites is reviewed. A key to Iranian scutacarid mites is also provided.
\end{abstract}

KEYWORDS - Heterostigmatina; new hosts record; Scutacarus; Imparipes; Heterodispus

ZOOBANK — 2AF34089-9D27-4A3E-B868-C6D19D7F747F

\section{INTRODUCTION}

The family Scutacaridae Oudemans, 1916 (Acari: Heterostigmatina) includes 25 genera and more than 800 species; all of them are fungivorous (Khaustov, 2008; Zhang et al., 2011; Khaustov et al., 2017). Most scutacarid mites are mainly associated with beetles, flies, and hymenopterans, especially various ants and bees (Ebermann, 1988; Khaustov, 2008; Ebermann and Moser, 2008; Ebermann et al., 2013). All species of this family have free living habits and some of them have both phoretic and non phoretic female forms (dimorphism) for example, the genus Archidispus Karafiat, 1959 which dimorphic forms are typical for these mites (Eber- mann, 1990, 1991a, b). Among the 25 described genera of this family, only six have been recorded from Iran until now: Heterodispus Paoli, 1911; Scutacarus Gros, 1845; Imparipes Berlese, 1903; Pygmodispus, Archidispus Karafiat, 1959 and Lophodispus Kurosa, 1972 (Mahunka and Rohde, 1970; Ebermann et al., 2003; Hajiqanbar and Khaustov, 2014; Loghmani et al., 2014; Katlav et al., 2015, 2016; Sobhi et al., 2017). In order to better characterize the fauna of this country, surveys were carried out in northwestern Iran.

\section{MATERIALS AND METHODS}

The study was conducted from June 2015 to May 2016 in northwestern Iran. The insect specimens 
were captured directly from their habitats and all sampled specimens were adults. Mite specimens were retrieved from their hosts using an Olympus stereomicroscope. Mites were cleared in lactoNesbitt solution and mounted on slides in Hoyer's medium. The morphology of mites was studied using a compound microscope (model BX51, Olympus, Tokyo, Japan) equipped with phase contrast illumination. The bee genus Andrena was identified with the help of Dr. A. Talebi (Department of Entomology, Faculty of Agriculture, Tarbiat Modares University, Tehran, Iran). The Tenebrionidae beetles were identified with the help of Maxim Nabozhenko (Russian Academy of Science, Russia). All ants were identified with the help of Dr. Bernhard Seifert (Department of Entomology, Senckenberg Museum für Naturkunde, Berlin, Germany). Materials were collected by the senior author and deposited in the Acarological Collection, Department of Entomology, Faculty of Agriculture, Tarbiat Modares University (TMU), Tehran, Iran.

\section{RESULTS}

\section{SYSTEMATICS}

\section{Family Scutacaridae Oudemans, 1916 Genus Heterodispus Paoli, 1911}

Type species: Imparipes elongates Tragardh, 1904, by original designation.

\section{Heterodispus (Heterodispus) turkmenistaniensis Khaustov and Chydyrov, 2005}

Heterodispus (Heterodispus) turkmenistaniensis Khaustov and Chydyrov, 2005, p. 155, Figures 1-5.

Material examined - Eight females, Ardabil province, Meshgin-shahr, Koli Olia village, $38^{\circ} 41^{\prime} \mathrm{N}$, 475'ㄹ, 29 May 2015, phoretic on the beetle Blaps mortisaga Reitter, 1904 (Coleoptera: Tenebrionidae).

World distribution - Turkmenistan, collected from soil of cucumbers (Khaustov and Chydyrov, 2005); Iran, Kerman province, associated with beetle Scarites (Scarites) procerus eurytus Fischer von Waldheim (Coleoptera: Carabidae) (Mortazavi, 2010), Northeastern Iran, associated with beetle
Gonocephalum pubiferum Reitter (Coleoptera: Tenebrionidae) (Loghmani, 2013), Northwestern Iran, Ardabil province (current study).

Remarks - Association between this mite and beetles of the tenebrionid genus Blaps is new. Considering previous and current records of this mite in Iran, it probably has a preference to be phoretic on beetles than on other insects.

\section{Genus Imparipes Berlese, 1903}

Type species: Imparipes histricinus Berlese, 1903, by original designation.

\section{Imparipes (Imparipes) comatus Mahunka, 1970}

Material examined - Two females, Ardabil province, Meshgin-shahr, Ahmad Abad village, $38^{\circ} 21^{\prime} \mathrm{N}, 47^{\circ} 35^{\prime} \mathrm{E}, 14$ May 2016, on ants Tapinoma tauridis Emery, 1925 (Hymenoptera: Formicidae).

World distribution - Hungary, from nest of Formica sp. (Hymenoptera: Formicidae) (Mahunka, 1970). It was also reported from France and Crimea to be phoretic on ants Tapinoma erraticum (Latreille) (Hymenoptera: Formicidae), Lasius niger (L.), Myrmica rufa Jerdon and Tetramorium caespitum (L.) (Khaustov, 2008); Iran (current study).

Remarks - Record of this species is new for mite fauna of Asia. Association between this mite and ant species Tapinoma tauridis is also new.

\section{Imparipes (Imparipes) histricinus Berlese, 1903}

Material examined - Two females, Ardabil province, Meshgin-shahr, Koli Olia village, $38^{\circ} 41^{\prime} \mathrm{N}$, 475'ㄹ, 25 May 2016, on ants Messor sp. (Hymenoptera: Formicidae).

World distribution - Angola, Australia, Austria, Bolivia, Brazil, Denmark, France, Germany, Hungary, Ireland, Italy, Lithuania, Malaya, Mongolia, Russia, Tunisia, Ukraine and former Yugoslavia associated with ants Tetramorium caespitum L. and Messor sp. (Hymenoptera: Formicidae) (Khaustov, 2008; Khaustov and Tolstikov, 2016); Iran, Razavi Khorasan province, associated with 
Cataglyphis cf. nodus (Brulle) (Hymenoptera: Formicidae) (Hajiqanbar, 2010); Northeastern Iran, associated with Temnothorax sp. (Hymenoptera: Formicidae) (Loghmani et al., 2014); Northwestern Iran, Ardabil province (current study).

\section{Imparipes (Imparipes) imaginatus Mahunka, 1981}

Imparipes (Imparipes) imaginatus Mahunka, 1981: p. 355, Figures 29-35.

Material examined - Four females, Ardabil province, Meshgin-shahr, $38^{\circ} 21^{\prime} \mathrm{N}, 47^{\circ} 43^{\prime} \mathrm{E}, 25$ May 2016, on ants Tetramorium sp. (Hymenoptera: Formicidae).

World distribution - Hungary, from ant nest (Mahunka, 1981); Austria (Ebermann, 2004); Russia, on ant Tetramorium caespitum L. (Khaustov and Tolstikov, 2016); Iran, Golestan province, phoretic on an unidentified ant (Hymenoptera: Formicidae) (Badoodam, 2014); Ardabil province (current study).

Remarks - The ant genus Tetramorium is a new phoretic host for this mite species.

\section{Imparipes (Imparipes) lentus Khaustov, 2008}

Imparipes (Imparipes) lentus Khaustov, 2008: p. 120, Figures 76 (1-4).

Material examined - Five females, Ardabil province, Meshgin-shahr, altitudes of Mount Sabalan, $38^{\circ} 21^{\prime} \mathrm{N}, 47^{\circ} 54^{\prime} \mathrm{E}, 25$ May 2016, on ants Tetramorium sp. (Hymenoptera: Formicidae).

World distribution - Crimea, Western Siberia, on ants Tetramorium caespitum L. (Hymenoptera: Formicidae) (Khaustov, 2008; Khaustov and Tolstikov, 2016); Iran (current study). Iran.

Remarks - This species is new for mite fauna of

\section{Imparipes (Imparipes) placidus \\ Khaustov and Chydyrov, 2004}

Imparipes (Imparipes) placidus Khaustov and Chydyrov, 2004: p. 97, Figures 35-41.

Material examined - Five females, Ardabil province, Meshgin-shahr, Mount Sabalan altitudes, $38^{\circ} 21^{\prime} \mathrm{N}$, 47 $7^{\circ} 54^{\prime} \mathrm{E}, 25$ May 2016, on ants Tetramorium sp. (Hymenoptera: Formicidae). Five females, Ardabil province, Meshgin-shahr, Gooshe Olia village, $38^{\circ} 44^{\prime} \mathrm{N}, 4^{\circ} 56^{\prime} \mathrm{E}, 12$ May 2016, on ants Lasius obscuratus Stitz, 1930 (Hymenoptera: Formicidae).

World distribution - Turkmenistan, associated with the ant Messor excursionis Ruszky (Hymenoptera: Formicidae) (Khaustov and Chydyrov, 2004); Iran, Isfahan province, phoretic on an unidentified ant (Hymenoptera: Formicidae) (Tajodin, 2013); Ardabil province (current study).

Remarks - Ants of the genera Tetramorium and Lasius are new phoretic hosts for this species.

\section{Imparipes (Imparipes) rafalskii Dastych, 1978}

Imparipes (Imparipes) rafalskii Dastych, 1978: p. 251, Figures 1-9.

Material examined - Two females, Ardabil province, Meshgin-shahr, Koli Olia village, $38^{\circ} 41^{\prime} \mathrm{N}$, 47 ${ }^{\circ} 5^{\prime} \mathrm{E}, 29$ May 2015, phoretic on the bee Andrena sp. (Hymenoptera: Andrenidae).

World distribution - Poland, phoretic on Dasypoda hirtipes (Fabricius) (Hymenoptera: Melittidae) (Dastych, 1978); Ukraine, phoretic on Bombus terrestris L. (Hymenoptera: Apidae) (Zaloznaya and Khaustov, 2007); Iran (current study).

Remarks - Record of this species is new for mite fauna of Asia. Bees of the family Andrenidae are also new recorded hosts for this mite species.

\section{Imparipes (Imparipes) tenuis Mahunka, 1981}

Imparipes (Imparipes) tenuis Mahunka, 1981: p. 358, Figures 40-43.

Material examined - Three females, Ardabil province, Meshgin-shahr, altitudes of Mount Sabalan, $38^{\circ} 21^{\prime} \mathrm{N}, 47^{\circ} 54^{\prime} \mathrm{E}, 25$ May 2016, on ants Tetramorium sp. (Hymenoptera: Formicidae).

World distribution - Hungary, from ant nests (Mahunka, 1981); Austria (Ebermann, 2004); Iran, Kerman province associated with an unidentified ant (Mortazavi et al., 2016); Ardabil province (current study).

Remarks - Association between this mite and ants of the genus Tetramorium is new. 


\section{Genus Scutacarus Gros, 1845}

Type species: Scutacarus femoris Gros, 1845 , by monotypy.

\section{Scutacarus remissus Khaustov, 2008}

Scutacarus remissus Khaustov, 2008: p. 246, Figures $173(1-3)$.

Material examined - Five females, Ardabil province, Meshgin-shahr, Koli Olia village, $38^{\circ} 41^{\prime} \mathrm{N}$, 4755’E, 25 May 2016, on ants Messor sp. (Hymenoptera: Formicidae).

World distribution - Crimea, phoretic on Messor sp. (Hymenoptera: Formicidae) (Khaustov, 2008); Iran (current study)

Remarks - This species is new for mite fauna of Asia.

\section{Scutacarus shivicki Lazauskene and Sevastianov, 1974}

Synonyms: S. frumentaceus Sevastianov, 1983; S. iharosi Mahunka \& Zaki, 1985; S. diversisetus Sevastianov \& Chydyrov, 1992; S. furatensis Sevastianov \& Zahida Al Douri, 1988.

Material examined - One female, Ardabil province, Meshgin-shahr, Koli Olia village, $38^{\circ} 41^{\prime} \mathrm{N}$, 475'ㄹ, 25 May 2016, on ants Messor sp. (Hymenoptera: Formicidae).

World distribution - Russia, Kazakhstan, Turkmenistan, Lithuania and Hungary from Soil and litter (Lazauskene and Sevastianov, 1974; Sevastianov, 1983; Mahunka and Zaki, 1985; Sevastianov and Chydyrov, 1992; Sevastianov and Zahida Al Douri, 1988); Iran, East Azarbaijan province, soil of alfalfa fields (Lotfollahy et al., 2009); Ardabil province (current study).

Remarks - This species has been recorded several times from soil and litter, and its phoretic relationship was hitherto unknown. Therefore, it is first record of phoresy (including ant genus Messor) for this mite species.

\section{Scutacarus subquadratus Khaustov and Chydyrov, 2004}

Scutacarus subquadratus Khaustov and Chydyrov, 2004: p. 101, Figures 53-58.

Material examined - Six females, Ardabil province, Meshgin-shahr, Guda Kahriz village, $38^{\circ} 36^{\prime} \mathrm{N}, 47^{\circ} 48^{\prime} \mathrm{E}, 7$ May 2016, on ants Cataglyphis sp. (Hymenoptera: Formicidae).

World distribution - Turkmenistan, associated with Tetramorium schneideri Emery (Hymenoptera: Formicidae) (Khaustov and Chydyrov, 2004); Iran, East Azarbaijan province, soil of alfalfa fields (Lotfollahy et al., 2009); Razavi Khorasan province associated with Cataglyphis cf. nodus (Brulle) (Hymenoptera: Formicidae) (Hajiqanbar, 2010); Northeastern Iran, associated with Tricholabiodes sp. (Hymenoptera: Mutillidae) and Cataglyphis cf. nodus (Loghmani et al., 2014); Ardabil province (current study).

\section{DISCUSSION ON THE SCUTACARID-FAUNA OF IRAN}

Forty five species of scutacarid mites recorded from Iran are distributed in genera Scutacarus (17 species), Imparipes (16), Archidispus (7), Heterodispus (2), Pygmodispus (2) and Lophodispus (1). Some species are well adapted to live in soil and litter, such as both representatives of the genus Pygmodispus (Ebermann et al., 2003) and some species of the genera Scutacarus and Imparipes (see Kamali et al., 2001; Lotfollay et al., 2009; Hashemi Khabir et al., 2013). All Archidispus species, Lophodispus and many Scutacarus and Imparipes species have been found associated to various coleopterans and hymenopterans. Mites were found on beetles of the families Carabidae and rarely Staphylinidae (Hajiqanbar and Khaustov, 2014; Loghmani et al., 2014; Katlav et al., 2015, 2016). Ants constitute the most dominant insect hosts for Lophodispus, Imparipes and Scutacarus species (Loghmani et al., 2014; Katlav et al., 2015; Sobhi et al., 2017a, b). However, a few species of Imparipes (I. paulyi, I. burgeri and I. rafalskii) and Scutacarus acarorum are phoretic on bees (Kazemi and Kamali, 2006; Loghmani et al., 2014; 
Kiani Bakiani et al., 2016). All 45 Iranian scutacarids could be identified using the following key.

\section{Key to Iranian scutacarid mites (females)}

1. Legs IV with four segments ...............29

— Legs IV with five segments ............... 2

2. Tibia IV with four setae ...... Pygmodispus......3

— Tibia IV with three setae .................. 4

3. Posterior sternal plate expanded; setae $c_{2}$ longer than $c_{1}$; setae $4 c$ spine-like.

.P. (Allodispus) latisternus Paoli, 1911

- Posterior sternal plate not expanded; setae $c_{2}$ and $c_{1}$ subequal; setae $4 c$ setiform.

.............. P. (Pygmodispus) calcaratus Paoli, 1911

4. Setae $c_{1}$ inserted on free margin of tergite $C$; tarsus IV seta $u^{\prime}$ absent ........... Heterodispus...... 5

- Setae $c_{1}$ inserted on central part of tergite C; tarsus IV seta $u^{\prime}$ usually present................6

5. Tibia IV seta $l^{\prime}$ extending beyond base of pretarsus; femur IV seta $d$ longer than genu IV seta v'.......... H. verrucosus Mahunka and Rohde, 1970

- Tibia IV seta $l^{\prime}$ never reaching to base of pretarsus; femur IV seta $d$ shorter than genu IV seta $v^{\prime} . \ldots \ldots \ldots$. H. turkmenistaniensis Khaustov and Chydyrov, 2005

6. Second pharyngeal pump weakly discernible; anterior margin of anterior sternal plate with crown of thin process .............. Lophodispus tapinoma Sobhi and Hajiqanbar, 2017

- Second pharyngeal pump much larger than first and third; anterior margin of anterior sternal plate without process .......................... 7

7. Tarsus IV gradually tapering to the apex; with two types of females, non-phoretic and phoretic, the latter with massive tibiotarsus I and large claw.... . Archidispus......8
- Tarsus IV with expanded base and abruptly becoming thin distally; with only one type of females, tibiotarsus I with middle-size claw, sometimes absent ........................ Imparipes......14

8. Setae $p s_{2}$ apart from $p s_{1}$; pretarsus IV short (6-7); setae $4 c$ modified, thickened basally...

......... A. irregularis Katlav and Hajiqanbar, 2016

- Setae $p s_{2}$ and $p s_{1}$ generally with joined basal rings; pretarsus IV with various sizes but longer than 7 ; setae $4 c$ not modified ....................... 9

9. At least dorsal setae $c_{1}, d$ and $f$ modified, expanded basally............................ 10

— All dorsal setae not modified, setiform.... .11

10. Dorsal setae $c_{2}$ modified, expanded basally; among ventral setae, only setae $4 a$ modified, dilated................. A. armatus (Karafiat, 1959)

- Dorsal setae $c_{2}$ not modified, setiform; among ventral setae, $4 a$ and $4 b$ modified, expanded basally.................. insolitus (Kurosa, 1974)

11. Setae $f$ distinctly longer than $h_{2}$; setae $2 b$ shorter than $2 a \ldots \ldots \ldots \ldots$....... bembidii (Karafiat, 1959)

- Setae $f$ distinctly shorter than $h_{2}$; setae $2 b$ longer than $2 a \ldots \ldots \ldots \ldots \ldots \ldots \ldots \ldots \ldots \ldots . . . \ldots \ldots 12$

12. Setae $3 b$ and $4 a$ not modified, setiform........................ A. esfarayenicus Hajiqanbar and Khaustov, 2014

- Setae $3 b$ and $4 a$ modified

13. Setae $4 b$ modified, thickened basally; setae $1 a$ setiform ................ A. minor Karafiat, 1959

- Setae $4 b$ not modified, setiform; setae $1 a$ modified, dilated................ . conspicuus Kurosa, 1978

14. Gnathosoma very wide, with subequal length and width ........... Subgenus I. (Sporichneutes)... I. (S.) intermedius Paoli, 1911 
— Gnathosoma always longer than its width ... 15

15. Tibiotarsus I with three solenidia; pretarsus IV with no claws .......... Subgenus I. (Apidacarus)... I. (A.) paulyi Ebermann and Fain, 2002

- Tibiotarsus I with four solenidia; pretarsus IV usually with claw ..... Subgenus I. (Imparipes)...16

16. Pretarsus IV very short, with thickening end..................... I. rafalskii Dastych, 1978

— Pretarsus IV not as above .17

17. Setae $3 b, 4 a$ and $4 b$ modified, expanded basally............ I. insulanus Delfinado et al. 1976

- Setae $3 b, 4 a$ and $4 b$ not modified, setiform .....18

18. Setae $f$ and $h_{1}$ lanceolate I. tataricus Sevastianov, 1964

- Setae $f$ and $h_{1}$ not lanceolate 19

19. Setae $3 c$ at the same level or posterior to $3 b \ldots 20$

- Setae $3 c$ anterior to $3 b \ldots \ldots \ldots \ldots \ldots . . . . . .21$

20. Setae $c_{1}$ and $d$ subequal; setae $f$ longer than $h_{1}$; setae $4 a$ shorter than $p s_{1} \ldots \ldots . . . .$. . I. imaginatus Mahunka, 1981

- Setae $c_{1}$ shorter than $d$; setae $f$ and $h_{1}$ subequal; setae $4 a$ longer than $p s_{1}$.... I. tenuis Mahunka, 1981

21. Setae $p s_{2}$ longer than half of $p s_{1}$ length $\ldots \ldots 22$

- Setae $p s_{2}$ not longer than half of $p s_{1}$ length ... 23

22. Setae $e$ and $h_{2}$ longer than $f$ and $h_{1}$; interval between setae $4 a$ longer than that between $4 b$.................. I. longisetosus Willman, 1951

- Setae $e$ and $h_{2}$ shorter than $f$ and $h_{1}$; interval between setae $4 a$ shorter than that between $4 b . . . . . . . . . . . . . . . . . . I . ~ c o m a t u s ~ M a h u n k a, 1970$
23. Setae $p s_{2}$ equal to half of $p s_{1}$ length. ... .............. I. longitarsus Delfinado et al., 1976

- Setae $p s_{2}$ shorter than half of $p s_{1}$ length 24

24. Setae $f$ longer than $h_{1}$ .25

- Setae $f$ not longer than $h_{1} \ldots \ldots \ldots \ldots \ldots . .26$

25. Setae $d$ longer than $h_{2}$; trochanter IV seta $d$ not reaching to base of tarsus ............... I. placidus Khaustov and Chydyrov, 2004

- Setae $d$ shorter than $h_{2}$; trochanter IV seta $d$ protruding base of tarsus ...... I. lentus Khaustov, 2008

26. Setae $f$ shorter than interval between their bases...................................27

- Setae $f$ longer than interval between their bases.................................. 28

27. Setae $d$ never reaching to bases of tergite EF setae; setae $4 b$ never reaching to posterior border of idiosoma ....................... I. kugitangensis Khaustov and Chydyrov, 2004

- Setae $d$ extending beyond bases of tergite EF setae; setae $4 b$ reaching to posterior border of idiosoma................................ I. burgeri Ebermann and Jagersbacher-Baumann, 2013

28. Setae $h_{1}$ distinctly longer than $h_{2}$; setae $p s_{1}$ and $h_{2}$ subequal ............. I. histricinus Berlese, 1903

- Setae $h_{1}$ shorter than $h_{2}$; setae $h_{2}$ distinctly longer than $p s_{1}$........... I. parapicola Delfinado et al., 1976

29. Tibiotarsus I without claw ............... 30

— Tibiotarsus I with claw .................. 32

30. Setae $h_{1}$ and $h_{2}$ distinctly thickened, with extremely large barbs ...... S. eucomus (Berlese, 1908)

- Setae $h_{1}$ and $h_{2}$ not thickened, with no large barbs..................................31 
31. Setae $h_{1}$ shorter than interval between their bases; setae $4 a$ and $h_{1}$ subequal....S. quadrangularis (Paoli, 1911)

- Setae $h_{1}$ longer than interval between their bases; setae $h_{1}$ longer than $4 a \ldots \ldots \ldots \ldots . .$. S. contiguus Delfinado et al., 1976

32. Setae $4 b$ absent S. ebermanni Sobhi and Hajiqanbar, 2017

- Setae $4 b$ present 33

33. Setae $e$ and $h_{2}$ reduced 34

- Setae $e$ and $h_{2}$ well developed... .36

34. Apodemes 5 well developed; secondary transverse apodeme (sta) present...........S. shajariani Sobhi and Hajiqanbar, 2017

- Apodemes 5 reduced; secondary transverse apodeme (sta) absent

35. Setae $p s_{1}$ and $p s_{2}$ subequal, barbed, longer than $4 a \ldots . . . . . . . . . . . . . .5$. remissus Khaustov, 2008

— Setae $p s_{1}$ longer than $p s_{2} ; p s_{1}$ weakly barbed, $p s_{2}$ smooth, both shorter than $4 a \ldots \ldots \ldots . .$. . iranicus Ebermann et al., 2003

36. Setae $f$ characteristically short, at least five times shorter than $e$ and $h_{2} \ldots \ldots \ldots \ldots . .$. . transfusionis Mahunka and Mahunka-Papp, 1980

— Setae $f$ well developed, not as above .37

37. Tibiotarsus IV with six setae. . .38

— Tibiotarsus IV with seven setae ... .39

38. Setae $4 b$ more than four times longer than $4 a$; setae $p s_{1}$ and $p s_{2}$ subequal..........S. subquadratus Khaustov and Chydyrov, 2004

- Setae $4 b$ about twice as long as $4 a$; setae $p s_{1}$ twice as long as $p s_{2} \ldots \ldots \ldots$.... apodemi Mahunka, 1963
39. Setae $f$ and $h_{1}$ pinnate; $h_{2}$ thickened with large barbs .................. S. plumosus (Paoli, 1911)

- Setae $f, h_{1}$ and $h_{2}$ not as above

40. Setae $c_{1}, d, f$ and $h_{1}$ clavate S. claviger (Paoli, 1911)

- Setae $c_{1}, d, f$ and $h_{1}$ not clavate

41. Setae $e$ and $h_{2}$ subequal, spine-like... S. acarorum (Goeze, 1780)

- Setae $e$ and $h_{2}$ in various length, not spinelike.

42. Barbed setae $f$ at least eight times longer than smooth setae $e$... S. communis Delfinado et al., 1976

- Setae $e$ longer than $f$ or $f$ only slightly longer than e................................43

43. Setae $e$ distinctly longer than $f$; setae $f$ and $h_{1}$ lanceolate... S. shivicki Lazauskene and Sevastianov, 1974

- Setae $f$ slightly longer than $e$; setae $f$ and $h_{1}$ not lanceolate.... .44

44. Setae $p s_{1}$ and $p s_{2}$ subequal, longer than $p s_{3}$; setae $f$ and $h_{1}$ subequal........... S. fragariae Rack, 1975

- Setae $p s_{1}$ longer than subequal setae $p s_{2}$ and $p s_{3}$; setae $h_{1}$ longer than $f \ldots \ldots \ldots \ldots \ldots . . .$. serotinus Sevastianov and Chydyrov, 1992

\section{ACKNOWLEDGEMENTS}

We are grateful to the following persons for help to identify the insect hosts: Drs. Ali Asghar Talebi, Maxim Nabozhenko and Bernhard Seifert.

\section{REFERENCES}

Badoodam S. 2014 - Heterostigmatic mite (Acari: Heterostigmata) associated with insect in East of Golestan Province [MSc Thesis] — Iran, Tehran: Tarbiat Modares University. 87pp, p 32. 
Dastych H. 1978 - Imparipes (Imparipes) rafalskii sp. nov. (Acari: Tarsonemina) a new species of Scutacarid mite from Poland - Bull. Acad. Pol. Sci., 26(4): 251-255.

Ebermann E. 1988 - Imparipes (Imparipes) pselaphidorum n. sp., a new scutacarid species phoretic upon African beetles (Acari, Scutacaridae; Coleoptera, Pselaphidae) - Acarologia, 29: 35-42.

Ebermann E. 1990 - Taxonomic consequences of the polymorphism found in scutacarids (Acari, Scutacaridae) - Ent. Mitt. Zool. Mus. Hamburg, 10(139-140): 29-42.

Ebermann E. 1991a - Records of polymorphism in the mite family Scutacaridae (Acari, Tarsonemina, Scutacaridae) - Acarologia, 32(2): 119-138.

Ebermann E. 1991b - Das Phänomen Polymorphismus in der Milbenfamilie Scutacaridae (Acari, Heterostigmata, Tarsonemina, Scutacaridae) - Zoologica, 47(141): 1-76.

Ebermann E. 2004 - Scutacaridae (Arachnida: Acari) In: Schuster R. (Ed.) Checklisten der Fauna Österreichs, No. 1, Biosystematics and Ecology Series, Österreichische Akademie der Wissenschaften, Wien, 22: 3145.

Ebermann E., Hajiqanbar H., Haddad Irani-Nejad K. 2003 - New records of phoretic and soil-living mites from Iran (Acari, Heterostigmata, Scutacaridae) — Rev. Suisse. Zool., 110: 247-253. doi:10.5962/bhl.part.80185

Ebermann E., Hall M., Hausl-Hofstätter U., JagersbacherBaumann J.M., Kirschner R., Pfingstl T., Plassnig E. 2013 - A new phoretic mite species with remarks to the phenomenon "sporothecae" (Acari, Scutacaridae; Hymenoptera, Aculeata) - Zool. Anz., 252: 234-242. doi:10.1016/j.jcz.2012.06.003

Ebermann E., Moser J.C. 2008 - Mites (Acari: Scutacaridae) associated with the red imported fire ant, Solenopsis invicta Buren (Hymenoptera: Formicidae) from Louisiana and Tennessee, U.S.A - Internat. J. Acarol., 34: 55-69. doi:10.1080/01647950808683706

Hajiqanbar H. 2010 - Some scutacarid mites (Acari: Scutacaridae) associated with ants (Hym.: Formicoidea) and their nests from Iran $-9^{\text {th }}$ European Congress of Entomology, Budapest, Hungary, p. 238.

Hajiqanbar H., Khaustov A.A. 2014 - First record of the genus Archidispus (Acari: Scutacaridae) from Iran with description of a new species - Pers. J. Acarol., 3:1-8. doi:10.22073/pja.v3i1.10124

Hashemi Khabir Z., Haddad Irani Nejad K., Akbari A. 2013 - Some of edaphic mesostigmatic and prostigmatic mites in Southwest of East Azerbaijan Province, Iran - In: Abstract Book of the $2^{\text {nd }}$ International Persian Congress of Acarology, 29-30 August 2017, Karaj, Iran, p. 13.
Kamali K., Ostovan H., Atamehr A. 2001 - A catalog of mites and ticks (Acari) of Iran - Islamic Azad University Scientific Publication Center, Tehran, 192 pp.

Katlav A., Hajiqanbar H., Talebi A.A. 2015 - A contribution to the knowledge of heterostigmatic mites (Acari: Prostigmata) in western Mazandaran Province, Northern Iran - Acarologia, 55: 311-320. doi:10.1051/acarologia/20152175

Katlav A., Hajiqanbar H., Talebi A.A. 2016 - Two remarkable new species of the superfamily Pygmephoroidea (Acari: Heterostigmata) associated with beetles (Coleoptera: Carabidae, Staphylinidae) Ann. Entomol. Soc. Am., 109: 136-144. doi:10.1093/aesa/sav099

Kazemi Sh., Kamali K. 2006 - New records of mites (Astigmata, Mesostigmata, Prostigmata) associated with Bombus argillaceus (Hymenoptera, Apoidea) from Iran - In: Abstract Book of the $12^{\text {th }}$ International Congress of Acarology, 21-26 August 2006, Amsterdam, The Netherlands, p. 90.

Khaustov A.A. 2008 - Mites of the family Scutacaridae of Eastern Palaearctic - Kiev. Akademperiodyka. pp. 291.

Khaustov A.A., Chydyrov P.R. 2004 - A new species of mites of the family Scutacaridae (Acari: Heterostigmata) associated with ants (Hymenoptera: Formicidae) from Turkmenistan - Acarina, 13(2): 155-157.

Khaustov A.A., Chydyrov P.R. 2005 - A new species of mites of the genus Heterodispus (Acari: Heterostigmata: Scutacaridae) from Turkmenistan - Acarina, 13(2): 155-157.

Khaustov A.A., Hugo-Coetzee E.A., Ermilov S.G. 2017 - A new genus of the mite family Scutacaridae (Acari: Heterostigmata) associated with Trinervitermes trinervoides (Isoptera: Termitidae) from South Africa - Zootaxa, 4258(5): 462-476. doi:10.11646/zootaxa.4258.5.4

Khaustov A.A., Tolstikov A.V. 2016 - The diversity, mite communities, and host specificity of pygmephoroid mites (Acari: Pygmephoroidea) associated with ants in Western Siberia, Russia - Acarina, 21(2): 113-136. doi:10.21684/0132-8077-2016-24-2-113-136

Kiani Bakiani S., Monfared A., Hajiqanbar H., Azhari Sh. 2016 - A survey on Apoidea (Insecta: Hymenoptera) bees and their associated mites in Fars Province, Iran — J. Insect Biodiver. Syst., 2(2): 285-299.

Lazauskene L.A., Sevastianov V.D. 1974 - Four new species of mites of family Scutacaridae (Trombidiformes) - Acta. Parasitol. Lituanica, 12: 199-204.

Loghmani A. 2013 - Heterostigmatic mites (Acari: Heterostigmatina) associated with insects in some parts of Northeastern Iran [MSc Thesis] — Iran, Tehran: Tarbiat Modares University, 102pp., p. 76. 
Loghmani A., Hajiqanbar H., Talebi A.A. 2014 - New records of mites of the superfamily Pygmephoroidea (Acari: Heterostigmatina) associated with insects from northeastern Iran and new host records - Syst. Appl. Acarol., 19(2): 154-159. doi:10.11158/saa.19.2.5

Lotfollahy P., Irani-Nejad K.H., Bagheri M., Valizadeh M., Khaustov A.A., Camerik A.M. 2009 - Pygmephoroid soil mite fauna of alfalfa fields and their distribution in Northwest of East Azarbaijan province, Iran Agricul. Sci., 19: 298-317.

Mahunka S. 1970 - Considerations on the systematics of the Tarsonemina and the description of new European taxa (Acari: Trombidiformes) - Acta. Zool. Acad. Sci. Hung., 16: 137-174.

Mahunka S. 1981 - The Pygmephoroid fauna of the Hortobágy National Park (Acari: Tarsonemida) — Fauna. Horto. Nation. Park, 1: 343-370.

Mahunka S., Rohde Jr. C.J. 1970 - A new scutacarid and some pyemotid mites from Iran - Acarologia, 12: 103105.

Mahunka S., Zaki A.M. 1985 - Scutacarus iharosi sp. n. and some new notes on the Tarsonemina fauna on Hungary - Mis. Zool. Hung., 3: 7-13.

Mortazavi A. 2010 — Prostigmatic mites (Acari:Prostigmata) associated with Coleoptera in some regions of Kerman province, Iran [MSc Thesis] - Iran, Tehran: Tarbiat Modares University, 146pp. p. 98.

Mortazavi A., Hajiqanbar H., Kamali K. 2016 - first record of Imparipes (Imparipes) tenuis Mahunka, 1981 (Acari: Scutacaridae) from Iran - In: Proceedings of 22th Iranian Plant Protection Congress, 27-30 August 2016, Karaj, Iran, p. 496.

Sevastianov V.D. 1983 - New species of mites of the genus Scutacarus (Trombidifoemes, Scutacaridae) Zool. Zhurnal., 62: 1487-1495. [in Russian]

Sevastianov V.D., Chydyrov P.R. 1992 - New species of mites of family Scutacaridae (TRombidiformes) from Turkmenistan - Vestn. Zool., 1: 21-28. [in Russian]
Sevastianov V.D., Zahida N.D. Al Douri. 1988 - New species of mites of cohort Tarsonemina (Trombidiformes) from wheat crops - Zool. Zhurnal., 67(7): 1080-1083. [in Russian]

Sobhi M., Hajiqanbar H., Mortazavi A. 2017a - First record of the rare genus Lophodispus (Acari: Heterostigmata: Scutacaridae) from Iran with description of a new species associated with ants (Hymenoptera: Formicidae) - Int. J. Acarol., 43(3): 239-244. doi:10.1080/01647954.2016.1256910

Sobhi M., Hajiqanbar H., Mortazavi A. 2017b - Two new myrmecophilous species of the genus Scutacarus (Acari: Prostigmata: Scutacaridae) with world keys to related species groups - Ent. Sci., 20(1): 292-301. doi:10.1111/ens.12255

Tajodin M. 2013 - Heterostigmatic Mites (Acari: Heterostigmatina) associated with insects in west of Isfahan Province [MSc Thesis] — Iran, Tehran: Tarbiat Modares University, 87pp, p. 58.

Zaloznaya L.I., Khaustov A.A. 2007 - First find of the mite Imparipes (Imparipes) rafalskii (Acati, Scutacaridae) in Ukraine - Vestn. Zool., 41(3): 266 [in Russian]

Zhang Z.-Q., Fan Q.-H., Pesic V., Smit H., Bochkov A.V., Khaustov A.A., Baker A., Wohltmann A., Wen T.-H., Amrine J.W., Beron P., Lin J.-Z., Gabrys G., Husband R. 2011 - Order Trombidiformes Reuter, 1909. In: Zhang, Z-Q. (ed.) Animal biodiversity: an outline of higher-level classification and survey of taxonomic richness - Zootaxa, 3148: 129-138.

\section{COPYRIGHT}

$((c)$ EY-No-ND Sobhi M. et al. Acarologia is under free license. This open-access article is distributed under the terms of the Creative Commons-BY-NC-ND which permits unrestricted non-commercial use, distribution, and reproduction in any medium, provided the original author and source are credited. 